\title{
The Effect Of Accounting Conservatism And Life-Cycle Stages On Firm Valuation
}

Park, Yonpae, (Email: parky@savstate.edu), Savannah State University

Chen, Kung H., (Email: kchen1@unl.edu), University of Nebraska, Lincoln

\begin{abstract}
This paper investigates how accounting conservatism affects the value-relevance of accounting information under different economic attributes. A firm's value is driven by the underlying economics, such as its production function, investment opportunity set, and risk. The corporate lifecycle stage can capture general differences in these underlying economics. From the perspective of the Feltham and Ohlson (1995)'s valuation model, this suggests that firms in different life-cycle stages have different financial characteristics that affect the value-relevance of the accounting information. Their valuation model depicts theoretically that, under conservative accounting, the expected growth in net operating assets affects a firm's market valuation. This paper predicts that the pricing multiples of the value components of the valuation model will differ in different corporate life-cycle stages and accounting conservatism will have a joint effect with the life-cycle stage on the value-relevance of accounting information. This study conducts its hypothesis tests using comprehensive proxies such as conservatism estimates from the valuation model and corporate life-cycle stages. These enable this study to examine the overall effects of accounting information, accounting conservatism as well as economic attributes on firm value. According to those comprehensive proxies, sample firms are classified into two conservatism groups, and three life-cycle stages. The results of this study provide evidence that accounting conservatism has a joint effect with the life-cycle stage on the value-relevance of accounting information.
\end{abstract}

\section{INTRODUCTION}

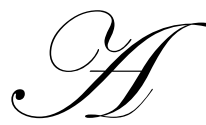

primary objective of financial reporting is to provide relevant and reliable information to interested third parties (Financial Accounting Standards Board [1978]). Financial reports are a means that managers use to communicate operating results and financial conditions of the firm to interested parties external to the firm. Users can then utilize this information to evaluate the performance and financial condition of the firm for investment decisions, fiduciary purposes, or other uses. However, not all firms reporting the same operating results and/or financial conditions have the same or similar market values. Other factors are likely to lead market values to differ among firms with similar operating results and financial conditions. Prior research suggests that accounting measurement rules and economic attributes play important roles in firm valuation using financial accounting numbers (Anthony and Ramesh [1992], Ahmed, Morton, and Schaefer [2000], and Penman and Zhang [2002]).

Feltham and Ohlson [1995] propose a theoretical firm valuation model suggesting that accounting conservatism plays important roles in firm valuations. In its conceptual framework, the Financial Accounting Standards Board [1980] identifies conservatism as one of the constraints on information usefulness. Few empirical studies (Stober [1996], Basu [1997], and Ahmed et al. [2000]) have investigated the effect of accounting conservatism on firm valuation. However, each of these studies investigated only limited aspects of accounting conservatism and focus only on a simple relationship between accounting conservatism and firm value. Other factors may affect firm values. The current economic attributes of a firm are likely to have an impact on the firm's choice of accounting 
measurement rules, and consequently its level of conservatism in its financial reports. For example, in the oil and gas industry, firms that use the Full Cost approach for exploration costs have been categorized as smaller, more highly leveraged, and younger than firms that use the Successful Efforts approach (Lilien and Pastena [1982]). Since prior studies on accounting conservatism have not considered other factors that may affect firm values, the role that accounting conservatism plays in firm valuations is yet to be established. Therefore, further investigation is necessary on the effect of accounting conservatism on firm values, given differences in economic attributes.

Using the Feltham and Ohlson [1995]'s valuation model (henceforth, FO model), this study examines (1) the effects of life-cycle stages on firm valuations and (2) the joint effects of accounting conservatism and life-cycle stages on firm valuations. Based on prior studies and the FO model, this study expects that the pricing multiples of the value components of the FO model will be different in different life-cycle stages and accounting conservatism will have a joint effect with the life-cycle stage on the value-relevance of accounting information. This study uses a pooled crosssectional time-series regression model to test the hypotheses. For the measure of firms' choices of accounting measurement rules, this study uses the conservatism estimate generated using the FO model. Life-cycle stages as defined by Black [1998] are used as a surrogate for firms' economic attributes. Sample firms are classified into two conservatism groups (CONSERVATIVE and AGGRESSIVE) and three life-cycle stages (GROWTH, MATURE and DECLINE). The results of this study show that the equity market processes accounting information differently for firms at different life-cycle stages. Furthermore, the choice of conservative accounting measurements in reporting financial results affects the relationship between life-cycle stages and firm values.

\section{ACCOUNTING CONSERVATISM AND CORPORATE LIFE-CYCLE}

A conservative accounting practice is likely to create "hidden reserves" and, in turn, generate higher expected future firm values in the long run (Penman and Zhang [2002]). Therefore, it is expected that companies applying conservative accounting practices will be valued higher by investors than companies following less conservative accounting practices. Stober [1996] and Ahmed et al. [2000], using FO valuation model, find that investors attach larger weights to abnormal earnings and net operating assets of firms following conservative accounting practices than those following less conservative practices. In addition, Ahmed et al. [2000] find that there are significant associations between proxies for conservative accounting procedures and the earnings persistence and conservatism multiples in the FO valuation model. ${ }^{1}$ Abarbanell and Bushee [1998], and Lev and Thiagarajan [1993] use the inventory costing method (LIFO or FIFO) as a proxy for the quality of accounting numbers in testing the informativeness of fundamental signals. They find that the choice of conservative accounting measurements in reporting financial results affects the market revisions on the firm's future earnings. In their firm valuation model, Feltham and Ohlson [1995] view accounting conservatism as a market expectation that the reported value of net assets of a firm will be less than the true economic value of the firm's net assets. ${ }^{2}$ In the context of Feltham and Ohlson [1995]'s valuation model, this paper defines accounting conservatism as the extent to which net operating assets are persistently understated relative to their economic values.

Since firms at different life-cycle stages have different economic characteristics, life-cycle stage has been used by financial analysts and academic researchers to describe economic attributes of a firm. The literature on lifecycle suggests that (1) life-cycle stages can explain differences in underlying economics of value-relevant attributes such as production function and investment opportunity set, (2) firms at different life-cycle stages need to manage business differently to be successful, and (3) awareness of a firm's specific life-cycle stage can gain understanding of where the firm has been and where the firm is going. These understanding can, in turn, help investors to obtain better evaluations of the firm (Lee and Nakicenovic [1988], Anthony and Ramesh [1992], and Black [1998]). ${ }^{3}$ Prior research provides evidences that informativeness of accounting measures differ at different stages of a firm's life cycle. Rao [1989] finds that the informativeness of unexpected earnings changes as a function of firm age. Anthony and Ramesh [1992] find firms at an early life-cycle stage (or growth stage) have a higher stock price reaction to unexpected positive sales growth and capital expenditure than firms at a later life-cycle stage (or decline stage). Gaver and Gaver [1993] point out that variation in the investment opportunity set leads to different corporate financing, dividend, and compensation policies. They found that growth firms use lower leverage, pay lower dividend, and use more stockbased incentive compensation than firms at other life-cycle stages. Amir and Lev [1996] show that financial 
accounting data are not informative about the future performance of early stage growth firms in the telecommunications industry. Black [1998] find the incremental information content of earnings and cash flows varies with life-cycle stages. However, lacking a model that offers a directional relation between accounting measures and life-cycle stage, prior research has tested the accounting implications of life-cycle intuitively.

Several analytical and empirical studies have examined the relationship between firms' economic attributes and accounting procedure choices. Watts and Zimmerman [1986, 1990] focus on earnings management and suggest that a firm's debt level affects manager's accounting procedure choices. Skinner [1993] provides evidence on the relation between firms' investment opportunities and accounting procedure choices. However, these studies find only limited evidences on the direct relationship between firms' economic attributes and accounting procedure choices because they argue that accounting procedure choices is directly attributable to debt levels and/or compensation contracts and firms' economic attributes affect accounting procedure choices only indirectly through debt levels and/or compensation contracts. This study examines the roles of operating earnings and net operating assets on equity valuation in the context of FO valuation model and investigates the implication of corporate life-cycle in a firm's market valuation. In addition, if investors perceive high inherent uncertainty about a firm's future cash flows for firms at an early growth stage or a late decline stage, then conservative accounting practices, which are presumed to minimize the subjective intervention of managers to measure accounting numbers, increase credibility of accounting data to investors.

\section{HYOPTHESIS DEVEMLOPMENT}

Accounting data can affect a firm's strategic decisions. Strategic decisions guide business activities (i.e., financial and operating activities) that change firm values. Studies on life-cycle show that the effectiveness of business activities in creating firm value varies with the life-cycle stage of the firm. Firms at different life-cycle stages often have different economic characteristics and firms at the same life-cycle stage often share similar economic characteristics (Anthony and Ramesh [1992], and Black [1998]). Both business activities of a firm and its economic characteristics, as represented by life-cycle stages, are important explanatory variables on the operating results reflected in financial statements, and the perceived future abnormal operating earning streams that determine firm value.

In addition to having an important role in equity valuation, accounting variables also convey information guiding strategic decisions and determining business activities. Both strategic decision and business activities underlie the creation of firm value. ${ }^{4}$ Even if two firms report the same accounting values, market reactions to their accounting measures can differ because of the differences in their economic attributes. Thus, it is important for a valuation model that considers the effect of firms' behavior in choosing business activities to incorporate these firms' economic characteristics. For instance, a firm at a growth stage may choose to expand even if the firm is not profitable, and another firm at a declining stage may choose to discontinue its operation even though the firm is making a handsome profit. In this setting, it is assumed that (1) both accounting variables and economic characteristics as represented by life-cycle are important determinants of a firm's strategic decisions and (2) investors value the expected future abnormal operating earnings to be produced from business activities. ${ }^{5}$

If the accounting system uses historical cost, a firm at a growth life-cycle stage should, on average, earn more than its cost of capital. Because a firm's investment projects have positive expected net present values (NPV) and the firm enjoys mark-up of its operating assets and equity, the firm will command positive abnormal operating earnings. Investors would place a positive weight on operating assets in evaluating firm values if they perceive the firm to be at a growth stage. According to the FO valuation model, the pricing multiples on operating earnings and net operating assets change as a firm proceeds through its life-cycle stages over time. Given that equity valuations relating to lifecycle stage, this paper hypothesizes that both operating earnings and net operating assets will have higher pricing multiples for firms at a growth stage than firms at other life-cycle stages. Based on the FO model, this paper tests the following hypothesis: 
H1: Investors place higher multiples on both abnormal operating earnings and operating assets for firms at growth stage than firms at mature or declining stage.

This paper defines accounting conservatism as an accounting practice, applied consistently over time, that keeps the book value of net operating assets low. ${ }^{6}$ The practice needs to be consistently applied over periods to distinguish it from temporary manipulations of accounting principles or accounting estimates to manage the reported earning. Examples of temporary manipulations of accounting are underestimations of valuation reserve for deferred tax assets or doubtful accounts to inflate earnings temporarily and overestimations of restructuring charges to reduce earnings temporarily. ${ }^{7}$ In the FO valuation framework, growth in investment is irrelevant if and only if the accounting is unbiased. ${ }^{8}$ Therefore, given a conservative accounting policy consistently applied over time, the market value of a firm's equity hinges on expected growth in investment in conjunction with other value-relevant accounting components. Conservative accounting implies that a firm has "hidden reserves" for future profits and hence the firm is likely to be rewarded for high growth in its net operating assets. ${ }^{9}$

Penman and Zhang [1999] demonstrate the interaction between conservative accounting and growth in investment with the cases of following accounting practices. Increases in LIFO reserve (layer) raise hidden reserves, and declines in the LIFO reserve (i.e., LIFO dipping) reduce hidden reserves. Similar results can be found in other accounting practices. Accelerated depreciation has no effect on net operating assets and earnings if there is no growth in fixed assets investment, but it reduces net operating assets and earnings (and creates hidden reserves) if investment in the fixed assets increases, ceteris paribus. If investments in the fixed assets decline, accelerated depreciation creates earnings through the liquidation of hidden reserves. Immediate expensing of $R \& D$ expenditures and advertising are conservative accounting practices. However, they have no effect on earnings relative to capitalizing and amortizing of the expenditures if these expenditures are not growing. In contrast, changes in R\&D or advertising investments with immediate expensing create hidden reserves.

In summary, conservative accounting practices applied consistently over time reduce contemporaneous earnings for firms with increases in investments. However, the market would likely assign high weights to the reduced earnings because of the increased hidden reserves that have potentials for higher future earnings from the reserves. On the other hand, a firm following conservative accounting can increase current earnings by reducing investments (or the rate of growth in investments), which makes the current earnings a poor indicator of future earnings. The market would likely assign low weights to the temporarily increasing earnings because of the decreased hidden reserves. To the extent that the joint effect of accounting policy and investment activity on hidden reserve or earnings is correctly interpreted by investors in pricing a firm's equity, the expected growth in operating assets along with accounting conservatism provides relevant information about the expected future value of the firm. ${ }^{10}$ Given the abundance of information, including both accounting and non-accounting information, investors have information to evaluate the effects of accounting conservatism on net operating assets, estimate the expected growth in investments, and assess joint effects of accounting conservatism and growth on the firms' expected abnormal operating earnings. ${ }^{11}$ Therefore, this leads to the following hypotheses:

H2a: A growth firm perceived as following conservative accounting practices by investors has a higher multiple on its abnormal operating earnings and/or operating assets than that of a growth firm perceived as following aggressive accounting practices.

H2b: Mature firms with differences in accounting practices have similar multiples on their abnormal operating earnings and/or operating assets.

H2c: A declining firm perceived as following conservative accounting practices by investors has a lower multiple on its abnormal operating earnings and/or operating assets than that of a declining firm perceived as following aggressive accounting practices. 


\section{EMPIRICAL MODEL}

This study uses a pooled cross-sectional and time-series regression model to test the hypotheses. For the measure of firms' choices of accounting measurement rules, this study uses the conservatism estimate generated using the FO model. Life-cycle stages as defined by Black [1998] are used as a surrogate for firms' economic attributes. This paper uses the following FO models to test the hypotheses:

$$
\begin{array}{ll}
o x_{i t+1}^{a}=w_{0}+w_{1} o x_{i t}^{a}+w_{2} o a_{i t}+\varepsilon_{i t+1} & (\text { Linear Information Model) } \\
g_{i t}=\alpha_{0}+\alpha_{1} o x_{i t}^{a}+\alpha_{2} o a_{i t}+\varepsilon_{i t} & (\text { Linear Valuation Model) }
\end{array}
$$

where $g_{i t}=$ unrecorded goodwill per share (i.e., $g_{i t} \equiv p_{i t}-b v_{i t}$ where $p$ is stock price and $b v$ is book value) for firm $i$ at year $t$,

$o x^{a}{ }_{i t}=$ abnormal operating earning per share of firm $i$ at year $t$,

$o a_{i t}=$ net operating assets per share of firm $i$ at year $t$,

$w_{1}=$ persistence in abnormal operating earnings per share,

$w_{2}=$ accounting conservatism in operating assets per share,

$\alpha_{l} \quad$ = pricing multiple on abnormal operating earnings,

$\alpha_{2} \quad$ = pricing multiple on net operating assets, and

$\varepsilon_{i t} \quad=$ random error term for firm $i$ at year $t$.

Equation (1) suggests that the expected future abnormal earnings are affected by both current abnormal earnings and operating assets. The weight on net operating assets $\left(w_{2}\right)$ represents the effect of conservatism on the expected future abnormal earnings. Firms using conservative accounting are likely to systematically understate their current operating assets. As a result, a firm following conservative accounting choices might have an economic potential to produce large abnormal earnings (relative to its stated net operating assets) in the future. The coefficients of two explanatory variables in equation (2), $o x^{a}{ }_{i t}$ and $o a_{i t}$, indicate the persistence of abnormal earnings and the conservatism of operating assets respectively (Feltham and Ohlson [1995]). The effect of accounting conservatism on firm values is tested using equation (2).

Based on life-cycle stage indicators used in Anthony and Ramesh [1992], and Black [1998], this paper classifies sample firm-year into GROWTH, MATURE and DECLINE life-cycle stages. ${ }^{12}$ The life-cycle stage indicators are capital expenditures, dividend payout ratio, sales growth percentage, and firm age. Each firm-specific indicator is calculated each year for each of the sample firms. The firm-specific indicator for each firm-year is compared with the industry quintiles of indicator for the same year to assign a score of 1 to 5 for each of the firmyear. ${ }^{13}$ Each firm-year is classified into a life-cycle stage based on a composite score obtained by summing the individual indicator scores. Testing of the second hypothesis is performed using the pooled cross-sectional and timeseries regression with intercept and slope dummy variables for different life-cycle stages with the following regression equation:

$$
\begin{aligned}
& g_{i t}=\alpha_{0}+\alpha_{1} o x_{i t}^{a}+\alpha_{2} o a_{i t}+\beta_{0} D_{m}+\beta_{1} D_{m} o x_{i t}^{a}+\beta_{2} D_{m} o a_{i t}+\gamma_{0} D_{d} \\
& +\gamma_{1} D_{d} o x_{i t}^{a}+\gamma_{2} D_{d} o a_{i t}+\varepsilon_{i t}
\end{aligned}
$$

where $D_{m}=$ dummy variable which is 1 for mature firm-year and 0 otherwise, and

$D_{d}=$ dummy variable which is 1 for decline firm-year and 0 otherwise.

Consistent with the first research hypothesis, the predictions in alternative form are as follows: 
H1: $\quad \beta_{1}<0 ; \gamma_{1}<0$, and/or

$\beta_{2}<0 ; \gamma_{2}<0$

To examine the joint effects of conservatism and life-cycle stage on the market reaction to valuation multiples, all firm-years in each life-cycle stage is divided into "CONSERVATIVE" and "AGGRESSIVE" strata by calculating the firm-specific average estimates of conservatism from the equation (1). To test the joint effects of accounting conservatism and life-cycle stage on firm valuation (hypotheses $\mathrm{H} 3 \mathrm{a}, \mathrm{H} 3 \mathrm{~b}$, andH3c), this paper tests the following regression equation for each life-cycle stage group:

$g_{i t}=\alpha_{0 l}+\alpha_{1 l} o x_{i t}^{a}+\alpha_{2 l} o a_{i t}+\beta_{0 l} D_{k}+\beta_{1 l} D_{k} o x_{i t}^{a}+\beta_{2 l} D_{k} o a_{i t}+\varepsilon_{i t}$

where $\quad l \quad=g$ for GROWTH firms, $m$ for MATURE firms and $d$ for DECLINE firms, and

$D_{k}=$ dummy variable which is 1 for AGGRESSIVE firms and 0 otherwise.

The pooled cross-sectional and time-series regression model is formulated as above in order to permit the intercept and coefficients to vary across the different level of accounting conservatism.

The figure 1 shows the partitioning scheme for the second hypothesis. In equation (5) and figure $1, \alpha_{01}, \alpha_{11}$ and $\alpha_{21}$ (where $l=g$ for GROWTH firms, $m$ for MATURE firms and $d$ for DECLINE firms) represent the intercept, persistence coefficient, and conservatism coefficient, respectively, for CONSERVATIVE firms. For the AGGRESSIVE firms, the intercept, the persistence, and conservatism coefficients are $\alpha_{01}+\beta_{01}, \alpha_{11}+\beta_{11}$ and $\alpha_{21}+\beta_{21}$, respectively. Hence, $\beta_{01}, \beta_{11}$ and $\beta_{21}$ represent the differences in the intercepts and coefficients between CONSERVATIVE firms and AGGRESSIVE firms. Consistent with the second research hypothesis, the predictions in alternative form are as follows:

H2a: $\quad \beta_{1 \mathrm{~g}}<0$ and/or $\beta_{2 \mathrm{~g}}<0$.

H2b: $\quad \beta_{1 \mathrm{~m}}=0$ and $/$ or $\beta_{2 \mathrm{~m}}=0$.

H2c: $\quad \beta_{1 \mathrm{~d}}>0$ and/or $\beta_{2 \mathrm{~d}}>0$.

Figure 1: Coefficients for each Sample Stratum for Hypothesis H2

\begin{tabular}{|c|c|c|c|c|c|}
\hline \multicolumn{2}{|c|}{ Life-Cycle Stage } \\
\hline Growth & \multicolumn{2}{c|}{ Mature } & \multicolumn{2}{c|}{ Decline } \\
\hline Conservative & Aggressive & Conservative & Aggressive & Conservative & Aggressive \\
\hline$\alpha_{0 g}$ & $\alpha_{0 g}+\beta_{0 g}$ & $\alpha_{0 m}$ & $\alpha_{0 m}+\beta_{0 m} \alpha_{l m}+$ & $\alpha_{0 d}$ & $\alpha_{0 d}+\beta_{0 d}$ \\
$\alpha_{l g}$ & $\alpha_{I g}+\beta_{l g}$ & $\alpha_{l m}$ & $\beta_{l m}$ & $\alpha_{I d}$ & $\alpha_{l d}+\beta_{l d}$ \\
\hline
\end{tabular}

$g_{i t}=\alpha_{0 l}+\alpha_{1 l} o x_{i t}^{a}+\alpha_{2 l} o a_{i t}+\beta_{0 l} D_{k}+\beta_{1 l} D_{k} o x_{i t}^{a}+\beta_{2 l} D_{k} o a_{i t}+e_{i t}$

where $\quad l=g$ for GROWTH firms, $m$ for MATURE firms and $d$ for DECLINE firms, and

$D_{k}=$ dummy variable which is 1 for AGGRESSIVE firms and 0 otherwise

\section{MEASUREMENT DESCRIPTORS}

This study measures the firm-specific level of accounting conservatism by calculating the firm-specific average estimates of conservatism from the equation (1) over a four-year period preceding the event year. ${ }^{14} \mathrm{FO}$ [1995] define that a firm's accounting of operating assets to be conservative if the conservatism coefficient is a positive, unbiased if zero, and aggressive if negative. To examine the effect of conservatism on the market reaction to valuation 
multiples, the sample is divided into CONSERVATIVE" and "AGGRESSIVE" strata. This study examines the relative conservatism to the industry median conservatism, which investors are assumed to do when they make investment decisions. The firm-specific average estimate of conservatism is compared with the industry median estimate, which is calculated from the equation (1) using all the firms with the same two-digit SIC code as the target firm. If the firm-specific conservatism coefficient is greater than the industry median coefficient, then the sample firm is categorized as "CONSERVATIVE," otherwise "AGGRESSIVE."15

To test the hypothesized relationships, sample firm-years are selected from the either COMPUSTAT PC Plus Active or Research data sets during 1982 through 1993 and classified into two conservatism groups (CONSERVATIVE and AGGRESSIVE) and three life-cycle stages (GROWTH, MATURE and DECLINE). To classify sample firm-years into life-cycle stages, this study uses the following four classification variables commonly used in prior research on life-cycle (Anthony and Ramesh [1992], and Black [1998]): age of the firm (AGE), percent sales growth (SG), capital expenditure divided by total value of the firm (CE), and annual dividend payout divided by net income (DP). AGE variables are obtained from Moody's Industrial Manuals and computed as the difference between the current year and the earliest year of incorporation for each firm-year. ${ }^{16}$ Other financial variables are computed using data from COMPUSTAT as follows:

$$
\begin{aligned}
& S G_{t}=\frac{S A L E S_{t}-S A L E S_{t-1}}{S A L E S_{t-1}} \times 100 \\
& C E_{t}=\frac{C E X P_{t}}{V A L U E_{t}} \times 100 \\
& D P_{t}=\frac{D I V_{t}}{I B E D_{t}} \times 100
\end{aligned}
$$

where $\quad$ SALES $=$ net sales $(\# 12)$,

CEXP = capital expenditure (\#128),

$V A L U E=$ market value of equity $(\# 24 \times \# 25)$,

$D I V=$ common stock dividends $(\# 21)$, and

$I B E D=$ income before extraordinary items and discontinued operations (\#18). ${ }^{17}$

These life-cycle classification variables are expected to signal differences in strategic emphases of firms in each of the life-cycle stages (Anthony and Ramesh [1992], and Black [1998]). ${ }^{18}$ For example, younger firms are more likely to have new technology or products (Pashley and Philippatos [1990]). Firms with high sales growth are typically in the early phase of firm development and have high growth opportunities. Firms in early life-cycle stages, on average, invest large amounts in plants and equipment. Low dividend payout is usually associated with early life-cycle stages because firms need cash to, among others, meet operating needs and pay for capital expenditures. In general, firms in early life-cycle stages, on average, exhibit higher sales growth, larger capital expenditures, and lower dividend payout ratios (Black [1998]).

A mature stage firm is characterized by mature product markets and considerable competition (Anthony and Ramesh [1992], and Black [1998]). Sales growth stagnates and market share remains unchanged or declines due to market competition. High levels of liquidity accumulate from past investments while new investments are limited. Hence, firms at mature stage are likely paying high dividends. Also, firms at the mature stage usually have excess capacity, and any further investment in capacity is likely to result in reduced profitability. As a result, firms at the mature stage are less likely to incur large capital expenditure. At decline stage, demand for the firm's products dies away, sales drop off significantly, losses are likely to occur, and dividends cease (Anthony and Ramesh [1992], and Black [1998]). The firm may pursue divesture to improve liquidity and maintain dividends rather than invest in plant and equipment. 


\section{SAMPLE SELECTION} criteria $^{19}$ :

The sample firm-years are selected for the period 1982 through 1993 that satisfy the following sampling

1. Sample firms should have the requisite accounting data and stock price data available from either COMPUSTAT PC Plus Active or Research data sets. ${ }^{20}$

2. Firms with SIC codes from 6000 to 6999 are excluded from the sample because these firms are financial firms, which are subject to regulatory requirements that are likely to affect the relation between market values and accounting numbers (Ahmed et al. [2000]).

3. Firm-years with abnormal operating earnings or operating assets which fell within the $1^{\text {st }}$ and $99^{\text {th }}$ percentiles are excluded from sample to mitigate the effects of extreme values.

4. Each sample firm-year can be classified into "CONSERVATIVE" and "AGGRESSIVE" strata by comparing the firm-specific average estimate of conservatism with the industry median estimate, which is calculated from the equation (1) using all the COPUSTAT firms having the same two-digit SIC code as the target firm.

Figure 2: Score Assignment to Industry Quintile

\begin{tabular}{|c|c|c|c|c|}
\hline \multirow{2}{*}{ Industry Quintile } & \multicolumn{4}{|c|}{ Life-Cycle Descriptors } \\
\cline { 2 - 5 } & AGE & SG & CE & DP \\
\hline $80 \%-100 \%$ & 1 & 5 & 5 & 3 \\
\hline $60 \%-80 \%$ & 2 & 4 & 4 & 3 \\
\hline $40 \%-60 \%$ & 3 & 3 & 2 & 3 \\
\hline $20 \%-40 \%$ & 4 & 2 & 1 & $4(2)^{*}$ \\
\hline $0 \%-20 \%$ & 5 & 1 & $5(1)^{*}$ \\
\hline
\end{tabular}

Note: * If the sum of scores for AGE, SG, and CE is low (i.e., smaller than 7.5), and DP is at the lowest (second lowest) quintile, then one (two) is assigned as the DP score for decline stage firm-years.

Using multiple life-cycle stage descriptors (i.e., AGE, SG, CE, and DP), this study classifies sample firms meeting the above criteria into life cycle stages (GROWTH, MATURE, and DECLINE) as follows: ${ }^{21}$

1. The four life-cycle stage descriptors (i.e., AGE, SG, CE, and DP) are calculated for each event year (i.e., relative-year 0) for each sample firm-year.

2. Industry quintiles are calculated for each of the descriptors for each event year using all the COMPUSTAT firms having the same two-digit SIC code as the target firm.

3. The four classification variable observations for each firm-year are assigned to each industry quintile of the same variable and they are given a score as shown in figure $2 .{ }^{22}$ In figure 2 , the composite score ranges from four to twenty. A low dividend payout could signal either high growth opportunities or liquidity problems. While a decline stage firm with liquidity problems would exhibit a low dividend payout, the firm is unlikely to be in the high quintile on the sales growth or capital expenditures variables. Therefore, if the sum of the scores for AGE, SG and CE is low (i.e., smaller than 7), and score for DP is five (four), then one (two) is assigned as DP score for decline stage firm-years.

4. Each sample firm-year is classified into life-cycle stages using the following procedure: (1) A firm-year is classified as a "GROWTH" stage observation if its composite score is between sixteen and twenty. (2) A firm-year is classified as a "MATURE" stage observation if its composite score is between nine and fifteen.

5. A firm-year is classified as a "DECLINE" stage observation if its composite score is between four and eight. ${ }^{23}$

Table 1 shows the sample selection criteria (Panel A), the sample frequency in each event year (Panel B), and in each accounting conservatism classification (Panel C) across the different life-cycle strata of sample firm-years. Table 2 reports the industry composition for the 713 firms that met data requirements. Not all industries have approximately equal member of firms included in the sample. Sample has a higher number of firms in the Retail Trade 
and Natural Gas Pipelines industries, and a lower number of firms in the Automotive, Diversified Companies, Construction industries. To control for industry effects, this study classifies sample firms into CONSERVATIVE and AGGRESSIVE strata, and GROWTH, MATURE and DECLINE strata by calculating the firm-specific average estimates of conservatism and life-cycle stage and comparing these with the industry medians. Firms are considered to be in the same industry if they have the same two-digit SIC code.

Table 1: Sample Selection

\begin{tabular}{|c|c|c|c|c|c|c|c|c|}
\hline \multicolumn{9}{|c|}{ Panel A : Sample Selection Process (Number of firm-years) } \\
\hline & \multicolumn{2}{|c|}{ EXPANDED } & \multicolumn{2}{|c|}{ UNCHANGED } & \multicolumn{2}{|c|}{ REDUCED } & \multicolumn{2}{|c|}{ Total } \\
\hline $\begin{array}{l}\text { 1. Firms with individual scores in the } \\
\text { relevant industries }\end{array}$ & \multicolumn{2}{|c|}{---} & \multicolumn{2}{|c|}{---} & \multicolumn{2}{|c|}{---} & \multicolumn{2}{|c|}{1627} \\
\hline 2. Firms with consecutive scores & \multicolumn{2}{|c|}{---} & \multicolumn{2}{|c|}{---} & \multicolumn{2}{|c|}{---} & \multicolumn{2}{|c|}{1492} \\
\hline $\begin{array}{l}\text { 3. Firms with top, middle or bottom } \\
\text { two deciles }\end{array}$ & \multicolumn{2}{|c|}{299} & \multicolumn{2}{|c|}{298} & \multicolumn{2}{|c|}{298} & \multicolumn{2}{|c|}{895} \\
\hline $\begin{array}{l}\text { 4. Firms with COMPUSTAT data } \\
\text { available }\end{array}$ & \multicolumn{2}{|c|}{277} & \multicolumn{2}{|c|}{281} & \multicolumn{2}{|c|}{275} & \multicolumn{2}{|c|}{833} \\
\hline 5. Non financial firms & \multicolumn{2}{|c|}{247} & \multicolumn{2}{|c|}{250} & \multicolumn{2}{|c|}{242} & \multicolumn{2}{|c|}{739} \\
\hline 6. Firms after excluding outliers & \multicolumn{2}{|c|}{238} & \multicolumn{2}{|c|}{244} & \multicolumn{2}{|c|}{231} & \multicolumn{2}{|c|}{713} \\
\hline 7. Firms with life-cycle descriptor data & \multicolumn{2}{|c|}{233} & \multicolumn{2}{|c|}{236} & \multicolumn{2}{|c|}{225} & & \\
\hline Panel B : Conservative and Aggressiv & $\mathrm{rm}-\mathrm{Ye}$ & es across I & e-Cycl & tages & & & & \\
\hline & GR & WTH & & URE & & LINE & & tal \\
\hline CONSERVATIVE & 83 & $(54.3 \%)$ & 173 & $(54.7 \%)$ & 135 & $(59.7 \%)$ & 391 & $(56.3 \%)$ \\
\hline AGGRESSIVE & 70 & $(45.7 \%)$ & 143 & $(45.3 \%)$ & 91 & $(40.3 \%)$ & 303 & $(43.7 \%)$ \\
\hline Total & 153 & $(100 \%)$ & 316 & $(100 \%)$ & 226 & $(100 \%)$ & 694 & $(100 \%)$ \\
\hline Panel C : Year Composition of Firm-Y & ss acro & Life-Cyc & Stages & & & & & \\
\hline & GR & WTH & & URE & & LINE & & tal \\
\hline 1984 & 12 & $(7.8 \%)$ & 28 & $(8.9 \%)$ & 38 & $(16.8 \%)$ & 78 & $(11.2 \%)$ \\
\hline 1985 & 13 & $(8.5 \%)$ & 29 & $(9.2 \%)$ & 25 & $(11.1 \%)$ & 67 & $(9.7 \%)$ \\
\hline 1986 & 17 & $(11.1 \%)$ & 38 & $(12.1 \%)$ & 26 & $(11.5 \%)$ & 81 & $(11.7 \%)$ \\
\hline 1987 & 16 & $(10.5 \%)$ & 32 & $(10.2 \%)$ & 24 & $(10.6 \%)$ & 72 & $(10.4 \%)$ \\
\hline 1988 & 22 & $(14.4 \%)$ & 43 & $(13.7 \%)$ & 28 & $(12.4 \%)$ & 93 & $(13.4 \%)$ \\
\hline 1989 & 18 & $(11.8 \%)$ & 37 & $(11.7 \%)$ & 27 & $(11.9 \%)$ & 82 & $(11.8 \%)$ \\
\hline 1990 & 31 & $(20.3 \%)$ & 52 & $(16.5 \%)$ & 31 & $(13.7 \%)$ & 114 & $(16.4 \%)$ \\
\hline 1991 & 24 & $(15.7 \%)$ & 56 & $(17.8 \%)$ & 27 & $(11.9 \%)$ & 107 & $(15.4 \%)$ \\
\hline Total & 153 & $(100 \%)$ & 315 & $(100 \%)$ & 226 & $(100 \%)$ & 694 & $(100 \%)$ \\
\hline
\end{tabular}


Table 2: Industry Composition for Sample Firms

\begin{tabular}{|c|c|c|}
\hline Industry & No. of Firms & Percent \\
\hline Aerospace & 26 & $3.6 \%$ \\
\hline Airline & 21 & $2.9 \%$ \\
\hline Apparel & 39 & $5.5 \%$ \\
\hline Automotive & 6 & $0.8 \%$ \\
\hline Chemical & 31 & $4.3 \%$ \\
\hline Construction & 8 & $1.1 \%$ \\
\hline Containers and Packaging & 18 & $2.5 \%$ \\
\hline Diversified Companies & 7 & $1.0 \%$ \\
\hline Domestic Oil Refining & 44 & $6.2 \%$ \\
\hline Drilling and Oil & 31 & $4.3 \%$ \\
\hline Electrical Equipment & 32 & $4.5 \%$ \\
\hline Environmental Control & 14 & $2.0 \%$ \\
\hline Food, Beverage, and Tobacco & 12 & $1.7 \%$ \\
\hline Machinery & 48 & $6.7 \%$ \\
\hline Motor Carrier & 40 & $5.6 \%$ \\
\hline Natural Gas Distribution & 33 & $4.6 \%$ \\
\hline Natural Gas Pipelines & 59 & $8.3 \%$ \\
\hline Paper and Forest Products & 23 & $3.2 \%$ \\
\hline Publishing and Broadcasting & 43 & $6.0 \%$ \\
\hline Railroad & 22 & $3.1 \%$ \\
\hline Retail Trade & 74 & $10.4 \%$ \\
\hline Specialty Chemical & 48 & $6.7 \%$ \\
\hline Telecommunications & 16 & $2.2 \%$ \\
\hline Textiles & 18 & $2.5 \%$ \\
\hline Total & 713 & $100 \%$ \\
\hline
\end{tabular}

\section{DESCRIPTIVE STATISTICS}

The variables used in the empirical models and their definitions are as follows: ${ }^{24}$

1. $\quad p$ : Stock price at the end of three months following the firm's fiscal year-end.

2. $g$ : Unrecorded goodwill which is measured as stock price minus book value of equity (\#60).

3. oa: Operating assets which are measured as book value of equity minus cash and marketable securities (\#1) and other investments and advances (\#32), plus short term debt (\#34), long term debt (\#9), preferred stock (\#130), and minority interest (\#38).

4. ox: Operating earnings which are measured as income before extraordinary items (\#18) minus interest income (\#62) plus interest expense (\#15), preferred dividends (\#19), and minority interest (\#49). ${ }^{25}$

This paper follows the variable definitions of Stober [1995] who views preferred stock and minority interest as debt, while treating deferred taxes and net pension assets as net operating assets. All variables used in the FO model are scaled by common shares outstanding (\#25) to reduce possible size effects. Table 3 shows summary statistics for the FO valuation model on the relation between the unrecorded goodwill and abnormal earnings and operating assets for the entire sample firms. The average multiple on abnormal operating earnings, $\alpha_{l}$, is 3.416, as compared to 5.215 in Ahmed et al. [2000]. The average coefficient on operating assets, $\alpha_{2}$, is 0.07 which is smaller than Stober [1996]'s 0.22 and Ahmed et al. [2000]'s 0.41. Panel B of Table 3 reports the Pearson correlation coefficients between unrecorded goodwill, abnormal operating earnings, and operating assets. The unrecorded goodwill $\left(G_{t}\right)$ and abnormal operating earnings $\left(O X_{t}{ }_{t}\right)$ are significantly positively correlated at the significance level of 0.01 . However, operating assets are not significantly associated with the unrecorded goodwill. There is a significant association between the abnormal operating earnings and operating assets. This association may introduce multicollinearity into the model estimation. This study examines the condition index, and fails to find any multicollinearity problems. ${ }^{26}$ 
Table 3: Estimation of Persistence, Conservatism, and Valuation Multiples over the Overall Period $(\mathbf{n}=\mathbf{3 5 6 5})$

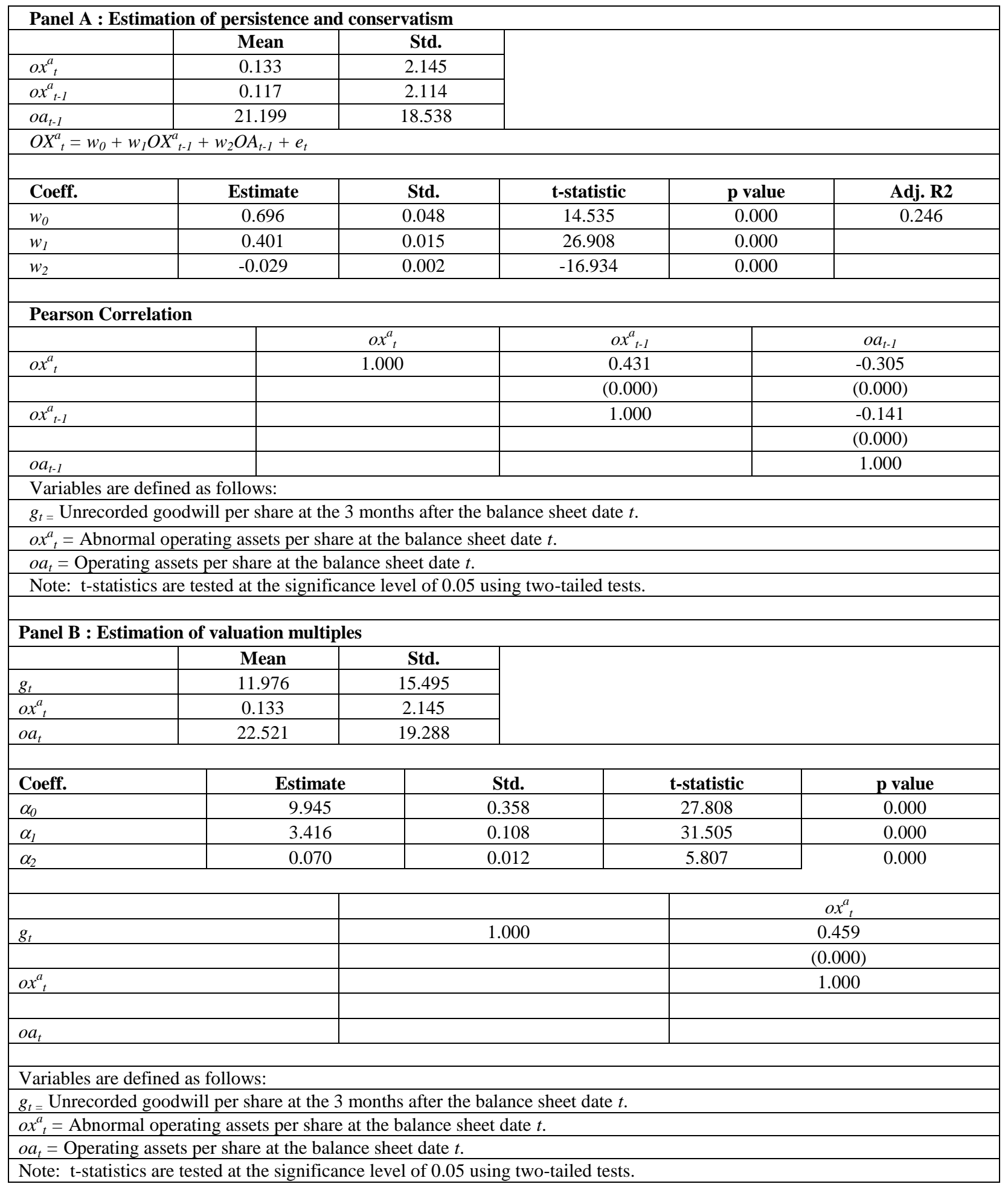




\section{EMPIRICAL RESULTS}

To test the first hypothesis (H1), the sample that met the data requirements (694 firms) is divided into GROWTH, MATURE, and DECLINE strata by comparing each life-cycle indicator with the industry quintiles of the indicator in the same year. Equation (4) is tested to examine whether the value-relevance of abnormal operating earnings and operating assets differ across life-cycle stages. The test results are shown in Table 4 and figure 3 . Figure 3 shows that the changes of the persistence and the conservatism coefficients of GROWTH firms are higher than those of MATURE firms and those of DECLINE firms. The market confers higher multiples to GROWTH firms' abnormal earnings and net operating assets than to firms at other life-cycle stages. Table 4 shows that the marginal effects of MATURE stratum are significantly negative $\left(\beta_{1}=-4.994\right.$ and $\left.\beta_{2}=-.249\right)$, and those of DECLINE stratum are negatively associated $\left(\gamma_{1}=-1.781\right.$ and $\left.\gamma_{2}=-.237\right)$. However, the effect on abnormal operating earnings for DECLINE firms, $\gamma_{1}$, is not significant, indicating that the value-relevance of abnormal operating earnings and operating assets differs for firms at different life-cycle stages. These findings suggest that investors form beliefs about the effectiveness of business activities based on the firm's life-cycle stage and value the expected future abnormal operating earnings to be produced from business activities accordingly. The results also coincide with the FO model's valuation framework in that expected growth affects the firm value.

Figure 3: The Effect of Corporate Life-Cycle on Valuation Multiples

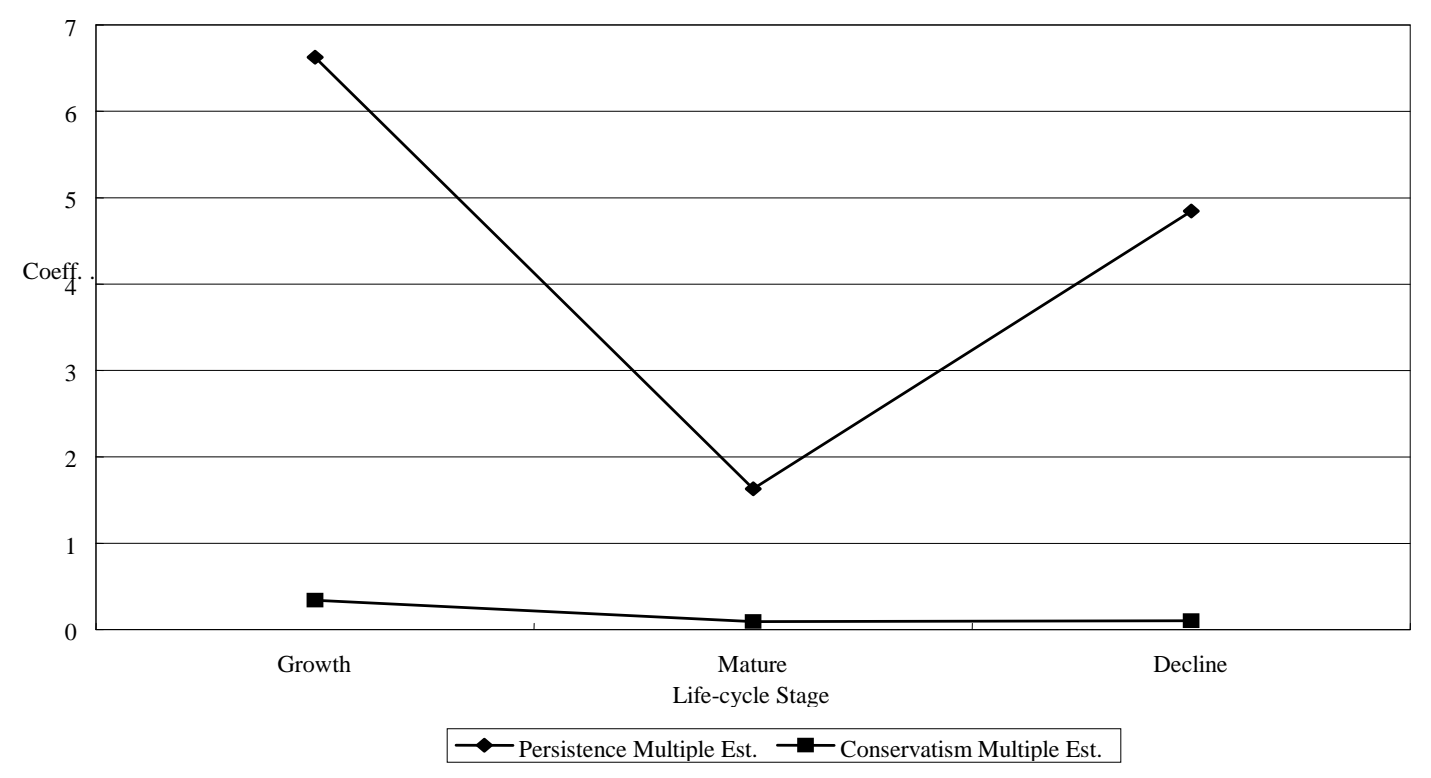

To examine the joint effects of conservatism and life-cycle stage on market reactions to valuation multiples, firms at each life-cycle stage sample are divided into "CONSERVATIVE" and "AGGRESSIVE" strata based on the relative positions by calculating the firm-specific average estimates of conservatism using Linear Information Model, equation (1), to the industry medians of all the firms that have the same two-digit SIC code. Equation (5) is tested across life-cycle stages to examine whether accounting conservatism affects the association between the life-cycle stage and firm valuation. The test results are shown in Table 5 and Figure 4. Figure 4 shows that the choice of accounting measurement rules affect firm values differently at different life-cycle stages. For firms at growth stage the persistence and conservatism coefficients of CONSERVATIVE firms are higher than those of AGGRESSIVE firms. For MATURE firms, the choice of accounting measurement rules is not likely to affect the value-relevance of abnormal earnings and net operating assets. The differences between the persistence and conservatism coefficients of CONSERVATIVE firms and those of AGGRESSIVE firms are smaller than those of firms at other life-cycle stages. 
However, at decline stage the persistence and conservatism coefficients of CONSERVATIVE firms are lower than those of AGGRESSIVE firms.

The results in Table 5 show that the marginal effects of less conservative accounting policies on both abnormal operating earnings and operating assets are significantly negative (i.e., $\beta_{1 \mathrm{~g}}=-3.453$ and $\beta_{2 \mathrm{~g}}=-.304$ ), indicating that investors price the GROWTH firms using conservative accounting practices higher than those using less conservative practices. The result suggests that investors bestow higher multiples on abnormal operating earnings and/or operating assets to firms perceived as conservative than the amounts they grant to aggressive firms. ${ }^{27}$ The results of the effects of accounting conservatism for MATURE firms show that the marginal effects of aggressive accounting policies on operating assets is significantly negative (i.e., $\beta_{2 \mathrm{~m}}=-.136$ ), indicating that the market prices higher the operating assets for conservative firms as expected. However, the marginal effect of accounting conservatism on abnormal operating earnings is not significant, indicating that investors do not price the effects of accounting conservatism on the wealth-creating factor as represented by abnormal operating earnings if they believe that the firm is at the mature stage. A firm at a mature stage is not likely to make many new investments and, as a result, the hidden reserve accumulated from accounting conservatism is likely to remain unchanged and not value-relevant for the future abnormal operating earnings.

Table 4: The Effect of Life-Cycle Stages on the Relation between Unrecorded Goodwill and Abnormal Earnings and Operating Assets for 694 Firm-years in the Period 1984 to 1991.

\begin{tabular}{|c|c|c|c|c|c|c|c|}
\hline \multicolumn{8}{|c|}{$g_{t}=\alpha_{0}+\alpha_{l} o x_{t}^{a}+\alpha_{2} o a_{t}+\beta_{0} D_{m}+\beta_{1} D_{m} o x_{t}^{a}+\beta_{2} D_{m} o a_{t}+\gamma_{0} D_{d}+\gamma_{1} D_{d} o x_{t}^{a}+\gamma 2 D_{d} o a_{t}+e_{t}$} \\
\hline PERIOD & Number & Coeff. & Est. & Std. & t-stat. & $\mathbf{p}$ & Adj R2 \\
\hline \multirow[t]{9}{*}{$1984-1991$} & 694 & $\alpha_{0}$ & 3.328 & 1.491 & 2.232 & 0.026 & 0.249 \\
\hline & & $\alpha_{1}$ & 6.626 & 1.027 & 6.45 & 0.000 & \\
\hline & & $\alpha_{2}$ & 0.341 & 0.043 & 7.944 & 0.000 & \\
\hline & & $\beta_{0}$ & 5.840 & 1.807 & 3.232 & 0.001 & \\
\hline & & $\beta_{1}$ & -4.994 & 1.069 & -4.672 & 0.000 & \\
\hline & & $\beta_{2}$ & -0.249 & 0.047 & -5.295 & 0.000 & \\
\hline & & $\gamma_{0}$ & 2.909 & 2.246 & 1.295 & 0.196 & \\
\hline & & $\gamma_{1}$ & -1.781 & 1.305 & -1.365 & 0.173 & \\
\hline & & $\gamma_{2}$ & -0.237 & 0.084 & -2.823 & 0.005 & \\
\hline \multicolumn{8}{|c|}{ Variables are defined as follows: } \\
\hline \multicolumn{8}{|c|}{$g_{t=}$ Unrecorded goodwill per share at the 3 months after the balance sheet date $t$. } \\
\hline \multicolumn{8}{|c|}{$o x_{t=}^{a}$ Abnormal operating earnings per share at the balance sheet date $t$. } \\
\hline \multicolumn{8}{|c|}{$o a_{t}=$ Operating assets per share at the balance sheet date $t$. } \\
\hline \multicolumn{8}{|c|}{$D_{m}=$ Dummy variable which is 1 for the firm-years in mature life-cycle, and 0 otherwise. } \\
\hline \multicolumn{8}{|c|}{$D_{d}=$ Dummy variable which is 1 for the firm-years in decline life-cycle, and 0 otherwise. } \\
\hline
\end{tabular}


Figure 4: The Effect of Conservatism and Life-cycle Stage on Valuation Multiples

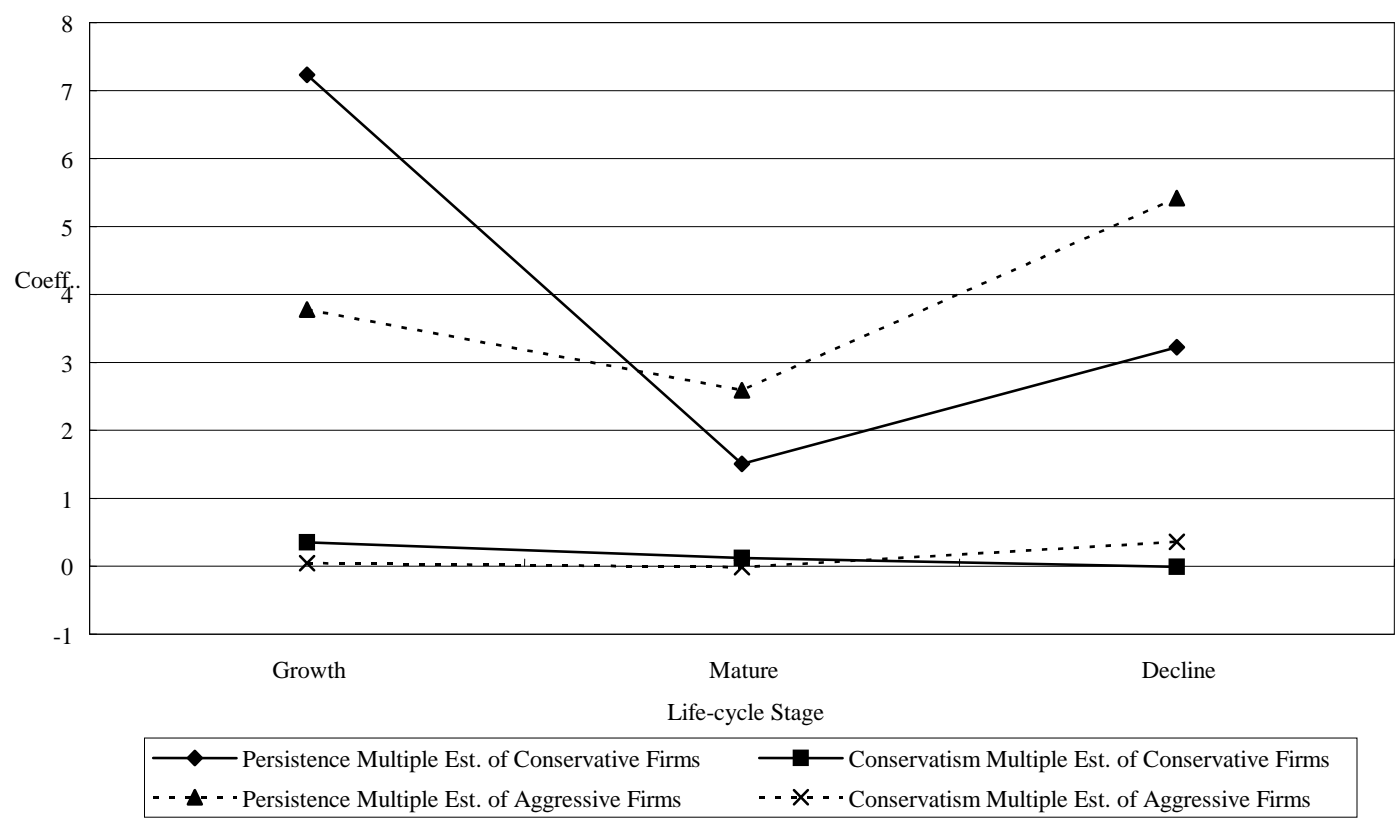

On the other hand, the results of the effect of accounting conservatism for DECLINE firms show that the marginal effects of less conservative accounting policies on both abnormal earnings and operating assets are significantly positive, which indicates that abnormal operating earnings and operating assets of DECLINE firms using conservative accounting policies are not value-relevant, and that investors price the DECLINE firms using less conservative accounting practices higher than those using conservative practices.

Table 5: The Effect Of Accounting Conservatism On The Relation Between Unrecorded Goodwill And Abnormal Earnings And Operating Assets Across Life-Cycle Stages For 694 Firm-Years In The Period 1984 To 1991

\begin{tabular}{|c|c|c|c|c|c|c|c|c|c|c|c|c|c|c|c|}
\hline \multicolumn{6}{|c|}{ GROWTH $(n=153)$} & \multicolumn{5}{|c|}{ MATURE $(n=316)$} & \multicolumn{5}{|c|}{ DECLINE $(n=226)$} \\
\hline Coeff. & Est. & Std. & \begin{tabular}{|l|} 
t-stat. \\
\end{tabular} & p & $\operatorname{Adj} R^{2}$ & Est. & Std. & t-stat. & p & $\operatorname{Adj} R^{2}$ & Est. & Std. & t-stat. & $\mathbf{p}$ & $\operatorname{Adj} R^{2}$ \\
\hline$\alpha_{0}$ & 4.233 & 1.415 & 2.992 & 0.003 & 0.657 & 9.799 & 1.711 & 5.726 & 0.000 & 0.095 & 7.773 & 1.400 & 5.553 & 0.000 & 0.350 \\
\hline$\alpha_{1}$ & 7.232 & 0.878 & 8.241 & 0.000 & & 1.510 & 0.466 & 3.243 & 0.001 & & 3.223 & 0.876 & 3.679 & 0.000 & \\
\hline$\alpha_{2}$ & 0.353 & 0.034 & 10.51 & 0.000 & & 0.121 & 0.029 & 4.101 & 0.000 & & -0.006 & 0.059 & -0.954 & 0.341 & \\
\hline$\beta_{0}$ & 3.433 & 2.746 & 1.250 & 0.213 & & 0.192 & 2.62 & 0.073 & 0.942 & & -2.820 & 2.219 & -1.271 & 0.205 & \\
\hline$\beta_{1}$ & -3.453 & 1.740 & -1.985 & 0.049 & & 1.080 & 0.809 & 1.335 & 0.183 & & 2.192 & 1.084 & 2.022 & 0.044 & \\
\hline$\beta_{2}$ & -0.304 & 0.112 & -2.717 & 0.007 & & -0.136 & 0.054 & -2.499 & 0.013 & & 0.366 & 0.095 & 3.858 & 0.000 & \\
\hline \multicolumn{16}{|c|}{ Variables are defined as follows: } \\
\hline \multicolumn{16}{|c|}{$g_{t=}$ Unrecorded goodwill per share at the 3 months after the balance sheet date $t$. } \\
\hline \multicolumn{16}{|c|}{$o x_{t}^{a}=$ Abnormal operating earnings per share at the balance sheet date $t$. } \\
\hline \multicolumn{16}{|c|}{$o a_{t}=$ Operating assets per share at the balance sheet date $t$. } \\
\hline \multicolumn{16}{|c|}{$D_{k}=$ Dummy variable which is 1 for the aggressive firm-years and 0 otherwise. } \\
\hline $\mathrm{No}$ & & & & & & 1 & $f 0$ & $\sin$ & 2 & de te & & & & & \\
\hline
\end{tabular}




\section{SUMMARY AND CONCLUSION}

Because prior studies on life-cycle have not considered the role of accounting procedure choice in firm valuation, the findings of those studies are not generalizable to firms following different accounting procedures. Using accounting valuation model proposed by Feltham and Ohlson [1995], this paper examines firm valuation attributable to (1) the effects of life-cycle stages and (2) the join effects of accounting conservatism and life-cycle stages. The results show that accounting conservatism affects the relationship between life-cycle stage and firm valuation. This chapter discusses the implications of those results.

The empirical evidences reject all the null hypotheses. This study finds that the market evaluates accounting information differently for firms at different life-cycle stages and accounting conservatism affects the relationship between life-cycle stage and firm valuation. Investors price higher (lower) for the GROWTH (DECLINE) firms using conservative accounting practices than firms using less conservative practices. For GROWTH firms, although conservative accounting practices reduce current earnings, the increased hidden reserves resulting from conservatism enable the accounting information to be informative. The result shows that investors bestow high multiple to decreasing earnings. For MATURE firms, accounting conservatism is not likely to affect investors' firm valuation in terms of abnormal operating earnings. On the other hand, DECLINE firms following conservative accounting that increase current earnings would make them poor indicators of future earnings. The evidence shows that the market assigns low weight to those temporarily increasing earnings.

Prior research on life-cycle stage (Anthony and Ramesh [1992] and Black [1998]) offers no directional relation between accounting information and life-cycle stage. Using FO model, this study provides directional hypotheses about the effect of life-cycle stage on value-relevance of accounting information. The results show that value-relevance of accounting information changes at different life-cycle stages and it is consistent with the results of Skinner [1993]. He finds that a firm's investments opportunity set relates to accounting procedure choices, even after controlling for managers' compensation schemes that are presumed to affect managers' choices of particular accounting procedures. In summary, this study contributes to the accounting valuation literature by providing evidence on the differential value-relevance of accounting information for firms using different accounting measurement rules at different life-cycle stages.

This study provides evidences that researches on accounting conservatism or life-cycle stage should take into consideration the different effects of accounting conservatism at different life-cycle stages. As an example, it is expected that the effect of conservative accounting choices on firm value will not be great in a study consisting mostly of firms at decline stage. In contrast, the result might be different if the sample firms are mostly at the growth stage. One of the motivations for this paper was to provide evidence concerning the extent to which the FO model is consistent with the data used in this paper by considering all the primary inputs (abnormal earnings, operating assets, and other information) to the FO model. This empirical test of the FO valuation model can provide evidence on its validity, which has been assumed in prior studies using FO model, and illustrate properties of it which would be valuable for future research.

\section{REFERENCES}

1. Abarbanell, J. and B. Bushee (1998), Abnormal Returns to a Fundamental Analysis Strategy, Accounting Review, 19-45.

2. Ahmed, A., R. Morton, and T. Schaefer (2000), Accounting Conservatism and the Valuation of Accounting Numbers: Evidence on the Feltham-Ohlson (1996) model, Journal of Accounting Auditing and Finance, 271292.

3. Amir, E. and B. Lev (1996), Value-relevance of Nonfinancial Information: The Wireless Communication Industry, Journal of Accounting and Economics, 3-30.

4. Anthony, J. and K. Ramesh (1992), Association between accounting performance measures and stock prices, Journal of Accounting and Economics, 203-227. 
5. Basu, S. (1997), The Conservatism Principle and the Asymmetric Timeliness of Earnings, Journal of Accounting and Economics, 3-37.

6. Black, E. (1998), Life-Cycle Impacts on the Incremental Value-Relevance of Earnings and Cash Flow Measures, The Journal of Financial Statement Analysis, 40-56.

7. Feltham, G. and J. Ohlson (1995), Valuation and Clean Surplus Accounting for Operating and Financial Activities, Contemporary Accounting Research, 689-731.

8. Financial Accounting Standards Board (1978), Statement of Financial Accounting Concepts No. 1: Objectives of Financial Reporting by Business Enterprises, Stamford, CT.

9. (1980), Statement of Financial Accounting Concepts No. 2:

Qualitative Characteristics of Accounting Information, Stamford, CT.

10. Gaver, J. and K. Gaver (1993), Additional Evidence on the Association between the Investment Opportunity Set and Corporate Financing, Dividend, and Compensation Policies, Journal of Accounting and Economics, 125-160.

11. Healy, P., K. Palepu, and A. Sweeney (1995), Do Firms Benefit from Expanded Voluntary Disclosure?, Working Paper.

12. Lang, M. and R. Lundholm (1993), Cross-Sectional Determinants of Analyst Ratings of Corporate Disclosures, Journal of Accounting Research, 246-271.

13. Lee, T. and N. Nakicenovic (1988), Technology life cycles and business decisions, International Journal of Technology Management, 411-426.

14. Lev, B. and S. R. Thiagarajan (1993), Fundamental Information Analysis, Journal of Accounting Research, 190-215.

15. Lilien, S. and V. Pastena (1982), Determinants of Intramethod Choice in the Oil and Gas Industry, Journal of Accounting and Economics, 145-170.

16. Liu, J. and J.A. Ohlson (1999), The Feltham-Ohlson (1995) Model: Empirical Implications, Working Paper.

17. Pashley, M. and G. Philipattos (1990), Voluntary divestitures and corporate life-cycle: some empirical evidence, Applied Economics, 1181-1196.

18. Penman, S. and X. Zhang (2002), Accounting Conservatism, the Quality of Earnings, and Stock Returns, The Accounting Review, 237-264.

19. Rao, G. (1989), The relation between stock returns and earnings: A study of newly-public firms, Working Paper.

20. Skinner, D. (1993), The Investment Opportunity Set and Accounting Procedure Choice, Journal of Accounting and Economics, 407-445.

21. Stober, T. (1996), Do prices behave as if accounting book values are conservative? Cross-sectional tests of the Feltham-Ohlson valuation model, Working Paper.

22. Watts, R. and J. Zimmerman (1986), Positive Accounting Theory. New Jersey: Prentice Hall.

23. _ (1999), Positive Accounting Theory: A Ten-year Perspective. The Accounting Review, 131-156.

\section{ENDNOTES}

${ }^{1}$ Ahmed et al. [1999] use accelerated depreciation, LIFO, R\&D expenditure, and advertising expenditure as proxies for accounting conservatism, and they find a significant relation between these proxies and the persistence and conservatism multiples in the FO valuation model.

${ }^{2}$ Basu [1997] defines accounting conservatism as the asymmetric accounting practice utilized in response to news whereby conservative firms write down net assets and reduce accounting earnings in response to "bad news" but not write up net assets and increase accounting earnings in response to "good news". Recognizing bad news or delaying the recognition of good news is also likely to result in under-valuation of net operating assets.

${ }^{3}$ The Institute of Management Accountants [1986, p. 13] argues "[a]t each stage of growth in an entity's life cycle, different measures of financial performance take on varying degrees of importance. Therefore, neither growth nor net income nor cash flows nor return on investment should be emphasized to the exclusion of other meaningful measures." 
${ }^{4}$ The first assumption is consistent with the observation that many firms use accounting measures such as return on investment (ROI) for performance evaluation and resource allocation (Anthony and Ramesh [1992]).

${ }^{5}$ Basically, this paper assumes that the market is efficient with respect to publicly available information.

${ }^{6}$ The following are among the examples of conservative accounting practices: (1) providing conservative LIFO accounting for inventories relative to FIFO, (2) expensing research and development (R\&D) expenditures rather than capitalizing and amortizing them, (3) accelerating depreciation methods and/or using short estimated asset lives, and (4) maintaining policies that consistently estimate high allowances for doubtful accounts, sales returns or warranty liabilities.

${ }^{7}$ The literature on manipulation of accounting principles or accounting estimates to manage reported earnings is extensive. However, in this paper, given an accounting policy applied consistently over time, earnings are assumed to be affected by change in investments. By calculating the average comprehensive conservatism index over four years (i.e., from -1 to -4 prior to event year), this paper minimizes the effects of those temporary conservative practices.

${ }^{8}$ In the FO model, growth positively affects firm value because the multiple on net operating assets, $\alpha$, increases as growth rate, $\omega_{22}$, increases.

${ }^{9}$ Intuitively, growth combined with conservative accounting makes it more difficult to recognize high earnings and hence the earnings will look more sustainable in the future.

${ }^{10}$ However, if a firm beliefs that the market misinterprets the implication of its accounting policy or the change in investment activities, it will try to correct such misinterpretation through voluntary disclosures.

${ }^{11}$ Large earnings or net assets do not necessarily lead to the maximization of firm value. Investment in capacity expansion at the wrong stage of a life cycle can lead to excess capacity and reduced profitability. Therefore, the joint-effects of conservative accounting and expected growth are expected to have different impacts on market prices at different life-cycle stages.

${ }^{12}$ In order to ensure that the empirical results are not driven by a single classification variable, a multivariate classification method is performed using quintiles of each life-cycle indicator.

${ }^{13}$ The score of 5 (1) is assigned for a firm-year with sales growth in the top (bottom) quintile of industry, capital expenditures ranked in the top (bottom) quintile of industry, dividend payout in the bottom (top) quintile of industry, and firm age ranked in the bottom (top) quintile of industry.

${ }^{14}$ Because of limitations in data availability, this paper estimates firm-specific conservatism with a relatively short period (-1 to -4). The impact of conservatism on abnormal earnings is predicted to revert to the mean quickly, so it is reasonable to estimate conservatism parameters over the relatively short period.

${ }^{15} 63 \%$ of overall sample firms are conservative in comparison to the industry average. However, the number of conservative firms is similar over the different voluntary disclosure strata (see Panel C of Table 1).

${ }^{16}$ If two firms are merged, the years in which the two firms were originally incorporated are compared and the earlier of them is used in computing AGE.

${ }^{17}$ Numbers in parentheses refer to COMPUSTAT data items.

${ }^{18}$ The financial classification variables (i.e., sales growth, capital expenditures, and dividend payout) are directly related to firm risk, so firms sorted on these variables could have a differential response to accounting measures, even without life-cycle considerations (Anthony and Ramesh [1992]). To minimize the effects of possible correlation of risk with life-cycle stage, firm age is used as a nonfinancial classification variable.

19 These sampling criteria are similar to those of Lang and Lundholm [1993] and Healy et al. [1995]. Since the calculation of CRR requires a 5-year window (+2 to -2$)$, event years analyzed in this study will be from 1984 to 1991.

${ }^{20}$ The stock price data are adjusted for stock splits and dividends. Including COMPUSTAT research data can reduce the self-selection bias from survivorship.

${ }^{21}$ Like prior research on life-cycle, this study uses multiple descriptors to reduce misclassification problem from a univariate classification. For instance, when a firm shows low dividend payout, multivariate classification can preclude misclassification of firms with liquidity problems that are not growth firms by considering other life-cycle stage descriptors (Black 1998). 
${ }^{22}$ Investors might put different weights on different life-cycle indicators. However as Anthony and Ramesh [1992] point out, it is difficult to measure different weights on each indicator. This paper assumes that four descriptors are equally weighted by investors.

${ }^{23}$ Although sample firms selected in this study are restricted to those with AIMR scores, the classification of life-cycle stage can be applied to any other firms by doing a comparison with the industry quintile.

${ }^{24}$ This paper follows the variable definitions of Stober [1995] who view preferred stock and minority interest as debt, while treating deferred taxes and net pension assets as net operating assets. All variables used in the FO model are scaled by common shares outstanding (\#25). Numbers in parentheses refer to the COMPUSTAT data item.

${ }^{25}$ This paper uses the annualized three-month Treasury Bill rate plus a risk-premium of $4 \%$ as a proxy for the cost of capital. Since Fama and French [1992] indicate that firm-specific risk factor (i.e., $\beta$ ) explains little of the crosssectional variation in stock price, this paper treats the cost of capital as cross-sectionally constant.

${ }^{26}$ This study examines the t-statistics based on White's heteroskedasticity-corrected covariance matrix, and fails to find any changes in the significance of t-statistics. The presence of significant autocorrelation in the residuals is also checked using the Durbin-Watson test. There is no evidence of significant autocorrelation in the residuals.

${ }^{27}$ The adjusted $R^{2}$ is .657, which is much higher than the value of adjusted $R^{2}$ found usually in earnings response coefficient (ERC) model. ERC model concerns only accounting earnings while the FO model incorporates both abnormal earnings and book value. 